University of Nebraska - Lincoln

DigitalCommons@University of Nebraska - Lincoln

Faculty Publications: Department of Entomology

Entomology, Department of

$1-2012$

\title{
Using Sex Pheromone Traps in the Decision-Making Process for Pesticide Application against Fall Armyworm (Spodoptera frugiperda [Smith] [Lepidoptera: Noctuidae]) Larvae in Maize
}

\author{
Ivan Cruz \\ Embrapa Milho e Sorgo, Brazil \\ Maria de Lourdes Corrêa Figueiredo \\ Embrapa Milho e Sorgo, Brazil \\ Rafael Braga da Silva \\ Universidade Federal de São Carlos, Brazil \\ Ivana Fernandes da Silva \\ Embrapa Milho e Sorgo, Brazil \\ Cristiane de Souza Paula \\ Embrapa Milho e Sorgo, Brazil
}

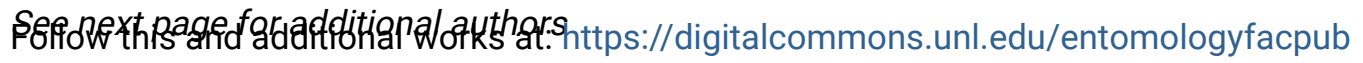

Part of the Agricultural Science Commons, Agronomy and Crop Sciences Commons, and the Entomology Commons

Cruz, Ivan; Figueiredo, Maria de Lourdes Corrêa; da Silva, Rafael Braga; da Silva, Ivana Fernandes; de Souza Paula, Cristiane; and Foster, John E., "Using Sex Pheromone Traps in the Decision-Making Process for Pesticide Application against Fall Armyworm (Spodoptera frugiperda [Smith] [Lepidoptera: Noctuidae]) Larvae in Maize" (2012). Faculty Publications: Department of Entomology. 530.

https://digitalcommons.unl.edu/entomologyfacpub/530

This Article is brought to you for free and open access by the Entomology, Department of at DigitalCommons@University of Nebraska - Lincoln. It has been accepted for inclusion in Faculty Publications: Department of Entomology by an authorized administrator of DigitalCommons@University of Nebraska - Lincoln. 
Authors

Ivan Cruz, Maria de Lourdes Corrêa Figueiredo, Rafael Braga da Silva, Ivana Fernandes da Silva, Cristiane de Souza Paula, and John E. Foster

This article is available at DigitalCommons@University of Nebraska - Lincoln: https://digitalcommons.unl.edu/ entomologyfacpub/530 


\title{
Using Sex Pheromone Traps in the Decision-Making Process for Pesticide Application against Fall Armyworm (Spodoptera frugiperda [Smith] [Lepidoptera: Noctuidae]) Larvae in Maize
}

Ivan Cruz, ${ }^{1}$ Maria de Lourdes Corrêa Figueiredo, ${ }^{1}$ Rafael Braga da Silva, ${ }^{2}$ Ivana Fernandes da Silva, ${ }^{1}$ Cristiane de Souza Paula, ${ }^{1}$ and John E. Foster ${ }^{3}$

1. Embrapa Milho e Sorgo, Caixa Postal 151, 35.701-970, Sete Lagoas, Minas Gerais State, Brazil

2. Programa de Pós-graduação em Ecologia e Recursos Naturais, Universidade Federal de São Carlos (UFSCar), Departamento de Ecologia e Biologia Evolutiva, Caixa Postal 676, 13.565-905, São Carlos, São Paulo State, Brazil

3. University of Nebraska-Lincoln, Department of Entomology, Insect Genetics Laboratory, Lincoln, NE 68583-0816, USA

Corresponding author - Ivan Cruz, email ivancruz@cnpms.embrapa.br

\begin{abstract}
The fall armyworm, Spodoptera frugiperda (Smith) (Lepidoptera: Noctuidae), is a major pest of maize and frequently demands control measures. The timing of insecticide application is a key factor in determining its efficiency, so an experiment was designed to investigate this. Application of insecticide was based on three criteria: (i) the number of trap-caught moths in a Delta-type trap with a commercial sex pheromone lure placed in the center of the target area, soon after plant emergence; (ii) the percentage of plants exhibiting pinhole-type damage $(10 \%$ or $20 \%)$, and (iii) the percentage of plants exhibiting shot hole-type damage (10\% or $20 \%$ ) compared to a check plot without any control measures. We found that the number of trap-caught moths was, compared to the other methods, the
\end{abstract}


best means of deciding on insecticide application in maize to control the fall armyworm. Using pheromone traps, we obtained the best performance of the insecticide Spinosad, causing $>90 \%$ larval mortality. Without insecticide application, maize yield reduction due to fall armyworm larva damage was $39 \%$.

Keywords: chemical control, fall armyworm, integrated pest management, pheromone trapping field, Zea mays

\section{Introduction}

The fall armyworm (FAW), Spodoptera frugiperda (Smith) (Lepidoptera: Noctuidae), is indigenous to the tropical regions of the western hemisphere, from Argentina to the USA, and is a major pest of maize in Brazil (Cruz 1995). Estimates suggest that over 400 million dollars of maize production are lost annually through crop damage (Cruz et al. 1999). FAW is considered to be a generalist feeder, exploiting a very wide host range of plants in several families (Yu et al. 2003; Rojas et al. 2004;Wyckhuys and O'Neil 2006). In Brazil, the insect is also an important pest of cotton.

Infestation levels by larvae of FAW can cause a $15-73 \%$ reduction in maize yield (Cruz and Turpin 1982, 1983; Cruz et al. 1996, 1999; Hruska and Gould 1997; Figueiredo et al. 2006). Synthetic pesticides are used to control the pest. However, the incorrect use of chemical pesticides by resource-poor rural growers may result in toxic exposure of farm workers (McConnell and Hruska 1993; Hunt et al. 1999) as well as significant environmental damage (Tinoco-Ojanguren and Halperin 1998).

Owing to the development of pest populations with varying degrees of resistance, FAW has become increasingly economically important (Pacheco-Covarrubias 1993). Alternatives for managing this pest are currently being explored, including the use of biological control agents (Rezende et al. 1995; Cruz et al. 1997, 2002; Figueiredo et al. 1999; Cisneros et al. 2002; Mendez et al. 2002; Molina-Ochoa et al. 2003), cultural techniques (Cruz et al. 1996, 1999; Farias-Rivera et al. 2003), host-plant resistance (Yu et al. 2003), genetically modified crops (Fernandes et al. 2003), and pheromones (Malo et al. 2001; Batista-Pereira et al. 2006).

In Brazil, most control measures against $S$. frugiperda, when adopted, involve the spraying of chemical insecticides, usually without consideration of the environmental consequences (Cruz 1995). Costa et al. (2005) found that in order to achieve effective control of S. frugiperda in maize and sorghum, two applications of pesticides should be made. The first application should take place $19 \mathrm{~d}$ after plant emergence (DAE), when the plants are at the vegetative stage V4 (four leaves completely expanded), and the second application at $47 \mathrm{DAE}$, without regard to pest density. Albuquerque et al. (2006), applying the insecticide tiametoxam + lambda-cyhalothrin as a foliar treatment at $8 \mathrm{~d}$ after plant emergence, achieved $86 \%$ pest control $7 \mathrm{~d}$ after spraying. Application of lufenuron at $12 \mathrm{DAE}$, when the leaves were scraped and perforated by FAW larvae reported in the same evaluation period, provided $75 \%$ pest control. Tomquelski et al. (2007) reported over $80 \%$ FAW larval mortality from Spinosad in two applications, the first at 15 DAE applied to maize, and the second $7 \mathrm{~d}$ afterward. 
A sequential sampling plan, based on Taylor's power law, also has been proposed to inform decision-making about FAW control in maize (Farias et al. 2001). According to Farias et al. (2001), a minimum of 15 samples should be taken before any decision should be made. The proposed method involves destroying the plant in order to observe the larvae located in the maize leaf whorl. No consideration was given to efficiency and cost.

Pheromones have been used for insect monitoring, mass-trapping, and mating disruption of a great diversity of insect pests. The female-produced sex pheromone of $S$. frugiperda is commercially available in several countries, including Brazil. Pheromones have been a useful tool for monitoring male populations (Mitchell et al. 1985, 1989; Adams et al. 1989; Pair et al. 1989; Lopez et al. 1990; Gross and Carpenter 1991; Weber and Ferro 1991; Malo et al. 2004; Batista-Pereira et al. 2006). Monitoring with pheromone traps is useful because pest pressure varies from farm to farm and over time. Knowledge of when and where adult pests are active and abundant provides a sensitive early-warning system to enable field sampling and/or control measures to be initiated at the appropriate time. Knowing whether or not pests are present allows the grower to avoid unnecessary pesticide applications or time-consuming sampling, and gives advance warning to protect crops when moth flights are first detected (Cruz et al. 2010b).

Traps catch only adult male moths but the plant damage is inflicted by larvae. Therefore, we cannot simply count moth numbers in the traps and ignore other factors such as temperature and crop growth stage, and even natural control. Trap captures are positively correlated with wind speed and temperature, and negatively correlated with relative humidity (Rojas et al. 2004). Using pheromone traps to monitor FAW adults is the best means of deciding on the number of pesticide applications necessary to control the pest in maize (Cruz et al. 2010a).

A study of the biology of the FAW (Cruz 1995) suggests that from egg mass deposition to approximately $10 \mathrm{~d}$ after the FAW larvae emerge will be between the third and the fourth instars and still very susceptible to the chemical insecticide, and also susceptible to the action of different species of natural enemies, but before significant plant damage is inflicted.

The first application of one pesticide should not be made immediately; rather, only 10 $\mathrm{d}$ after the capture of the three or more moths in the trap (Cruz 2008). If a second or third application is necessary, the pesticide's residual period of action should be considered. For example, for a four-day residual period the second pesticide application should be at least $14 \mathrm{~d}$ after the first one. In addition to effectiveness, the choice of the insecticide to be used in an integrated pest management program should present little or no harm to nontarget organisms, such as the pest's natural enemies and pollinators.

The aim of our study was to examine the effectiveness of a chemical insecticide applied to maize plant to control FAW larvae, based on three decision tools.

\section{Materials and methods}

The experiment was carried out at the Embrapa Corn and Sorghum Research Center, in

Sete Lagoas, Minas Gerais State, Brazil. Plots of the maize hybrid BRS 1030 were laid out 
in a randomized block design, with seven treatments and six replications. Each plot comprised 10 rows, $10 \mathrm{~m}$ long and were irrigated as needed. Plots within each block were separated from one another by 10 maize rows, $10 \mathrm{~m}$ long. Between blocks, the separation was made by 14 maize rows, $10 \mathrm{~m}$ long.

The decision as to when a standard chemical insecticide should be applied was based on three different criteria: (i) the number of captured adult insects in pheromone traps, (ii) the percentage of plants showing pinhole-type damage, and (iii) the number of plants showing shot hole-type damage. More specifically, the treatments were:

1) Insecticide application at $10 \mathrm{~d}$ after the capture of three $S$. frugiperda adult moths in a pheromone trap (FT1).

2) Two insecticide applications: the first one as FT1 and the second application (FT2) after the capture of three $S$. frugiperda adults, initiating the counting in the trap on the fourth day after the first insecticide application.

3) Insecticide application at $10 \%$ of plants with pinhole-type damage.

4) Insecticide application at $20 \%$ of plants with pinhole-type damage.

5) Insecticide application at $10 \%$ of plants with shot hole-type damage.

6) Insecticide application at $20 \%$ of plants with shot hole-type damage.

7) Check plot.

A commercial lure, produced by Chemtica International (Bio Spodoptera) and placed inside a Delta-type trap, was placed in the center of the plot, soon after plant emergence. It was fastened by a wooden stem at an initial height of $1 \mathrm{~m}$ above the soil surface. As the plants grew, the trap was lifted upward, so that it was always above the plants.

The insecticide "Tracer" (Spinosad) was applied as an aqueous suspension at $50 \mathrm{~mL}$ per hectare, using a backpack-manual sprayer at $40 \mathrm{psi}\left(2.8 \mathrm{~kg} / \mathrm{cm}^{2}\right)$ and a regular flat fan nozzle (Cruz and Santos 1984). Spraying was carried out in the morning, between 08:00 and 10:00 $\mathrm{h}$. This insecticide is widely used in Brazil, being legally registered for managing insect pests of several crops of economic importance, such as beans, citrus, coffee, corn, cotton, potato, sorghum, soybeans, and tomato. The commercial product comprises molecules - "spinosyns" - which have high insecticidal activity, especially against Lepidoptera (Crouse et al. 2001), but low toxicity to mammals (Bret et al. 1997; Sparks et al. 1998; Yano et al. 2002; Williams et al. 2003). Studies in sweetcorn have shown Spinosad to be very effective against the European corn-borer, while conserving its natural enemy complex (Musser and Shelton 2003).

Evaluations of the number of insects captured in the traps as well as the percentage of plants with pinhole- or shot hole-type damage were made daily. To determine the infestation level based on type of damage in each corresponding plot, two rows of maize were chosen at random. The percentage of infested plants was determined visually in these rows, and spraying was initiated when the optimum point was reached. Infestation was determined for all treatments before each insecticide application: in each experimental plot, the number of insect pest larvae per plant in a sample of 10 plants was counted. Plants were cut at the base and brought to the laboratory where caterpillars were counted and labeled according to the field plot from which they originated. The average number of 
collected caterpillars per plant was computed and thus the percentage of infested plants. Live caterpillars were maintained individually in laboratory conditions, inside plastic cups containing an artificial diet, in order to observe any parasitoid that might emerge. Twentyfour hours after spraying, the numbers of dead and live insects per plant and infestation level were evaluated by a similar procedure. At harvest, grain yield numbers were recorded.

\subsection{Statistical analyses}

Data from the experiment were analyzed by one-way analysis of variance (ANOVA) using the computer program SISVAR (Ferreira 2000). Treatment means were compared using the Scott-Knott test $(P=0.05)$ (Scott and Knott 1974). Before running the ANOVA, tests were conducted to determine whether the data set met the necessary assumptions. The Burr-Foster Q-test was used to test equality of variance. For testing the normality of the data, the W-test of Shapiro and Wilk was used following the description of both tests found in Anderson and McLean (1974). Transformations were used to normalize the data as suggested by Ostle and Mensing (1975). Regression analyses were applied to determine insecticide efficiency and grain yield in relation to insecticide application time.

\section{Results}

The number of captured adult insects in the pheromone traps suggested an earlier requirement for the first application of insecticide, using the criterion of $10 \mathrm{~d}$ after the first threemoth capture in pheromone traps (Table 1, Figure 1). Using the pinhole-type damage criterion at the level of $10 \%$ or $20 \%$ infested plants, the requirement for control occurred at $17 \mathrm{~d}$ and $24 \mathrm{~d}$, respectively. Using the same percentages of infested plants, but based on shot hole-type damage, the requirement for pest control occurred at $34 \mathrm{~d}$ and $43 \mathrm{~d}$ after the first three-moth capture in the pheromone traps.

Pest infestation before insecticide application varied significantly among treatments. Using the pheromone trap criterion (one application, or first application in the case of two applications), the average infestation level in both plots was similar: $11.7 \%$ and $8.3 \%$, respectively. It was also lower than the average found in the other plots, with an average of $45.4 \%$ of infested plants (Table 1). There was no significant difference among these treatments.

As expected, there was a significant reduction of infestation level after insecticide application; however, an infestation level below $2 \%$ was verified only for those plots in which the insecticide was applied, based on pheromone trap capture. The average infestation level in plots where the insecticides were applied, based on pinhole or shot hole damage, varied from $11.7 \%$ to $15 \%$ (Table 1). Higher reduction of infestation level on FT plots could be due to earlier stage larvae being more susceptible to the insecticide. Larval mortality was significantly higher on those FT plots, with a minimum of $91 \%$ mortality. Using the pinhole and shot hole damage criteria to apply the insecticide, the mortality rate was much less, varying from $61.9 \%$ to $78.9 \%$. 
Table 1. Effect of insecticide application decision criterion on percentage of plant infestation by Spodoptera frugiperda (Smith) (Lepidoptera: Noctuidae), efficacy of application, and yield of maize

\begin{tabular}{|c|c|c|c|c|c|c|c|c|}
\hline \multirow[b]{2}{*}{$\begin{array}{l}\text { Spraying } \\
\text { decision }^{1}\end{array}$} & & \multirow[b]{2}{*}{$\begin{array}{c}\text { Spraying } \\
\text { time }^{2}\end{array}$} & \multicolumn{3}{|c|}{ Plant infestation $(\%)^{3}$} & \multirow[b]{2}{*}{$\begin{array}{l}\text { Larval mortality } \\
\qquad(\%)^{3}\end{array}$} & \multicolumn{2}{|c|}{ Maize yield ${ }^{3}$} \\
\hline & & & $\begin{array}{c}\text { Before } \\
\text { spraying }\end{array}$ & $\begin{array}{c}\text { After } \\
\text { spraying }\end{array}$ & Mean & & (kg/ha) & $\%$ \\
\hline FT1 & & 10 & $11.7 \mathrm{~A}$ & $1.7 \mathrm{~A}$ & $6.7 \mathrm{~A}$ & $91.0 \mathrm{~B}$ & $7577 \mathrm{C}$ & 84 \\
\hline \multirow[t]{2}{*}{ FT1 + FT2 } & FT1 & 10 & $8.3 \mathrm{~A}$ & $0.0 \mathrm{~A}$ & $4.2 \mathrm{~A}$ & $100.0 \mathrm{~B}$ & $8969 \mathrm{D}$ & 100 \\
\hline & FT2 & 27 & $28.3 \mathrm{~B}$ & $3.3 \mathrm{~A}$ & $16.8 \mathrm{~B}$ & $93.9 \mathrm{~B}$ & & \\
\hline PTD 10\% & & 17 & $43.3 \mathrm{~B}$ & $11.7 \mathrm{~B}$ & $27.5 \mathrm{C}$ & $78.9 \mathrm{~A}$ & $7079 \mathrm{C}$ & 79 \\
\hline PTD 20\% & & 24 & $38.3 \mathrm{~B}$ & $16.7 \mathrm{C}$ & $27.5 \mathrm{C}$ & $77.8 \mathrm{~A}$ & $7062 \mathrm{C}$ & 79 \\
\hline STD $10 \%$ & & 34 & $56.7 \mathrm{~B}$ & $13.3 \mathrm{C}$ & $35.0 \mathrm{C}$ & $74.0 \mathrm{~A}$ & $6323 \mathrm{~B}$ & 70 \\
\hline STD 20\% & & 43 & $43.3 \mathrm{~B}$ & $15.0 \mathrm{C}$ & $29.2 \mathrm{C}$ & $61.9 \mathrm{~A}$ & $5723 \mathrm{~A}$ & 64 \\
\hline Check & & & -4 & -5 & & & $5515 \mathrm{~A}$ & 61 \\
\hline Mean & & & $32.9 \mathrm{~b}$ & $8.8 \mathrm{a}$ & & & & \\
\hline
\end{tabular}

1. FT $=$ Pheromone traps (three moths/trap; 1 and 2, first and second insecticide application, respectively); PTD = pinhole-type damage; STD = shot hole-type damage.

2. Days after first three-moth capture in pheromone traps.

3. Means followed by the same capital letter in a column are not significantly different according to ScottKnott test $(P \leq 0.05)$.

4. Percentage plant infestation in the check plot in each evaluation period was quite similar to the corresponding values for the plots where the insecticide was to be applied.

5. No significant change in relation to previous evaluation.

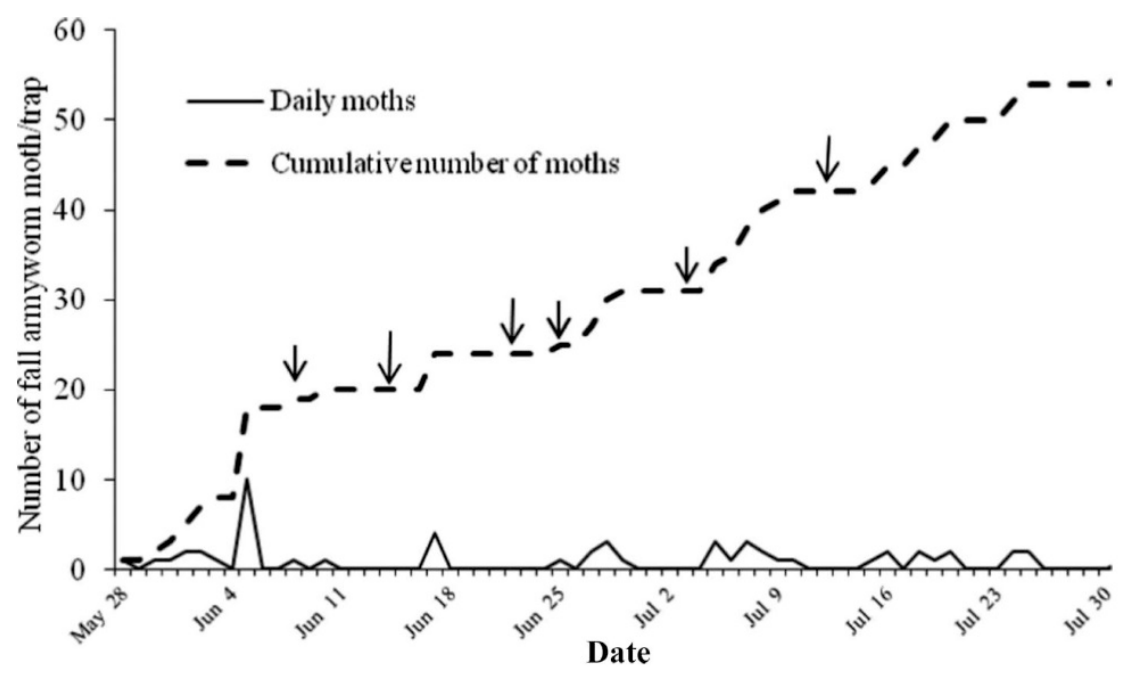

Figure 1. Daily and cumulative number of Spodoptera frugiperda (Smith) (Lepidoptera: Noctuidae) moths captured in pheromone traps and time of insecticide application (arrows) in maize.

Although the efficacy of an insecticide could be considered satisfactory in eliminating the insect target, in some cases, it was not sufficient for yield reduction to be avoided altogether. Maize yield varied from $5515 \mathrm{~kg} / \mathrm{ha}$ (check plots) to $8969 \mathrm{~kg} / \mathrm{ha}$ (two insecticide applications): a significant difference of $39 \%$ between the two averages. We found that two 
insecticide applications, based on FT criteria, to be the best treatment. These plots provided a significantly better harvest than all the other treatments (Table 1). A maize yield above 7 metric tonnes per hectare was obtained from insecticide-treated plots based on FT or pinhole damage criteria. Application of insecticide, using the $20 \%$ of infested plants exhibiting the shot hole damage criterion, did not prevent yield reduction. A similar yield was obtained from check plots.

\section{Discussion}

FAW moths fly to the maize field soon after plant emergence, as indicated by the sex pheromone trap (Figure 1). At this time, maize seedlings are very susceptible to pest damage and can be killed by the larvae (Cruz 1995). The first insecticide treatment was applied $10 \mathrm{~d}$ after capturing a cumulative number of three moths in pheromone traps. Up to this point, the cumulative number of captured moths was 20. Out of this total, 18 moths were captured within the 6-d period before insecticide application. As the field sex ratio of FAW is ca. 0.5 , and the egg incubation period is $3 \mathrm{~d}$ (Cruz 1995), the larval population by the time of insecticide application could be expected to be relatively high, mainly composed of susceptible, early-stage larvae. Indeed, we found that larval mortality exceeded $91 \%$ when insecticide was applied during this stage (Table 1). Insecticide application based on the $10 \%$ pinhole damage criterion occurred $7 \mathrm{~d}$ later than the application based on FT criteria. At this time, the accumulated number of captured moths was 24 , and larvae were older, resulting in a decreased mortality rate of $78.9 \%$. In fact, the efficiency of the insecticide had a negative and linear correlation with spraying time (Figure 2). Delaying insecticide application decreased the insecticide's effectiveness and did not significantly reduce the damage due to larval feeding. Consequently, the relationship between time when a conventional insecticide is applied to control larvae of $S$. frugiperda and maize yield was linear and negative (Figure 3).

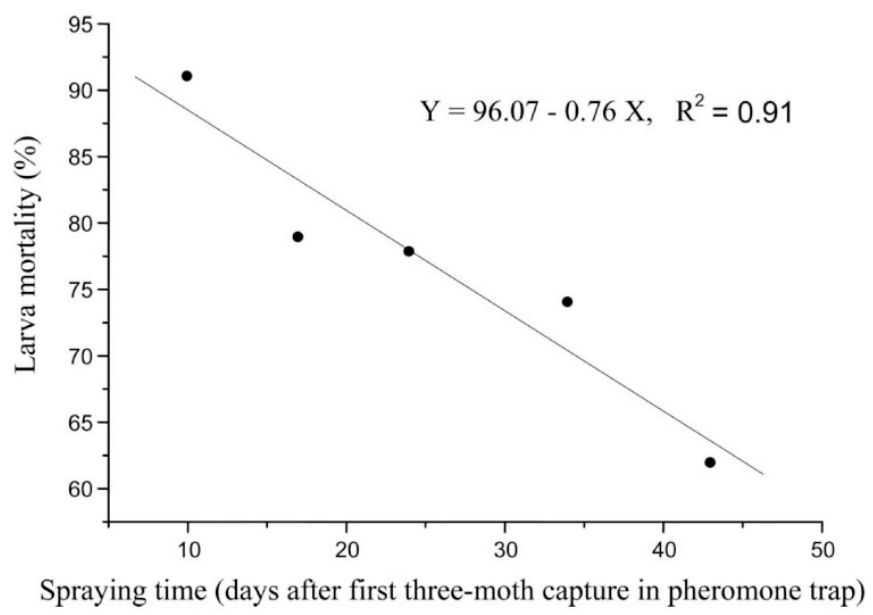

Figure 2. Relationship between larval mortality and application time of a chemical insecticide against Spodoptera frugiperda (Smith) (Lepidoptera: Noctuidae). 


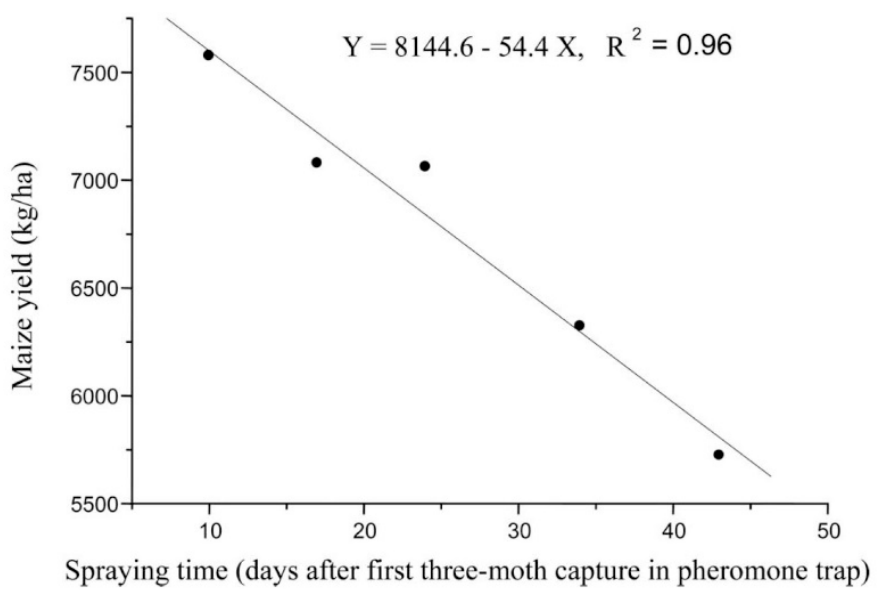

Figure 3. Relationship between maize crop yield and timing of application of a chemical insecticide against Spodoptera frugiperda (Smith) (Lepidoptera: Noctuidae) larvae.

Malo et al. $(2001,2004)$ tested commercial lures and found that the Chemtica and Trecé lures, used with delta traps, were best for monitoring S. frugiperda males in Mexico, with the Chemtica lure providing the greatest captures of moths, followed by Trecé and Pherotech lures. However, Malo et al. (2001) pointed out that the number of males caught was very low (a mean of 1.37 moths per trap per observation date, or $0.37 \mathrm{male} /$ trap/night) in comparison, for example, to 150 moths/trap/night reported by Gutiérrez-Martínez et al. (1989) in the central area of Chiapas State, Mexico, or elsewhere, where FAW sex pheromone lures have been evaluated (Mitchell et al. 1985; Adams et al. 1989; González and Caballero 1990). The reason for the low capture of moths reported by Malo et al. (2001) was the low FAW population during the study, once the traps caught a majority of the FAW males (Mitchell et al. 1985; Gutiérrez-Martínez et al. 1989). Another possibility could be that FAW males from the study region respond less to the commercial sex pheromone lures compared with populations elsewhere. As Figure 1 shows, the number of males caught was also low (a total of 54 adults captured during 64 consecutive days, or 0.84 male/trap/night), but sufficient to generate a larval population sufficiently large to cause significant crop loss, if no control measures were used (Table 1). This also takes into consideration the low natural enemy population in the area (Figure 4). In fact, this low population could be expected, once chemical insecticide has been applied in the adjacent area. 


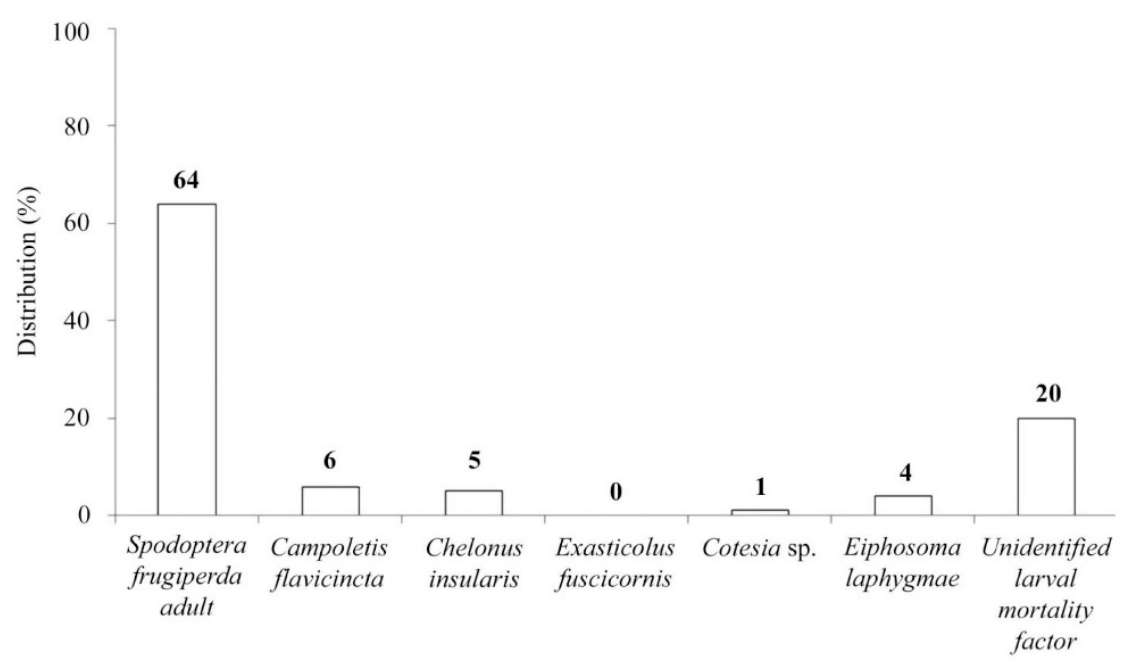

Figure 4. Distribution of Spodoptera frugiperda (Smith) (Lepidoptera: Noctuidae) adults and larval parasitoids originating from larvae collected in experimental maize field prior to insecticide application.

The existence of at least two races of $S$. frugiperda ("maize" and "rice") in the New World can lead to misinterpretation about the potential risk of damage to either crop. Both races contain the same three major pheromone components in gland extracts of females, but exhibit differences in both the concentrations and relative proportions of the compounds (Lopez-Edwards et al. 1999; Nagoshi and Meagher 2004; Busato et al. 2004; Virla et al. 2008). Also, both races may be collected in a single trap containing pheromone (Lima and McNeil 2004; Groot et al. 2008). Furthermore, it is difficult to determine the predominant race by visual means. However, in Brazil the race separation can be facilitated by the maize or rice cropping system (spatial and temporal distribution) and the feeding habits of the pest. For example, the insect is a key pest of maize, contrary to the situation in rice, where the insect is minor pest. There is no rice production in the area where the experiment was conducted, which is isolated from the main rice production area by a distance of more than $1500 \mathrm{~km}$. Brazil has about 2.8 million hectares of rice, of which about half is located in the south with only one growing season per year, whereas the area under corn is more than 13.4 million hectares, grown over two seasons. Therefore, we assumed that the insects collected in pheromone traps were predominantly of the corn race, and therefore the data obtained are valid for this crop. Furthermore, the pheromone is specific to the corn strain of $S$. frugiperda and has proved to be efficient in collecting moths (Batista-Pereira et al. 2006). Hence, the timing of application of a chemical insecticide based on FAW captures in pheromone traps can reduce the amount of plant damage from the pest and protect the yield in maize. In other words, when application of the insecticide is performed earlier, it provides greater efficiency of the control than when applied later in the season. For example, when FAW infestation occurs shortly after plant emergence, which is common in Brazil (Cruz et al. 2010b), the efficiency of the insecticide and the maize grain yield will be direct and inversely related to application time. 


\section{References}

Adams RG, Murray KD, Los LM. 1989. Effectiveness and selectivity of sex pheromone lures and traps for monitoring fall armyworm (Lepidoptera: Noctuidae) adults in Connecticut sweet corn. J Econ Entomol. 82(1):285-290.

Albuquerque FA, Borges LM, Iacono TO, Crubelati NCS, Singer AC. 2006. Eficiência de inseticidas aplicados em tratamento de sementes e em pulverização, no controle de pragas iniciais do milho. Rev Bras Milho e Sorgo. 5(1):15-25.

Anderson VL, McLean, RA. 1974. Design of experiments a realistic approach. New York: Marcel Deker, Inc. 418 p.

Batista-Pereira LG, Stein K, Paula AF, Moreira JA, Cruz I; Figueiredo MLC, Perri Jr. J, Correa G. 2006. Isolation, identification, synthesis and field evaluation of the sex pheromone of the Brazilian population of Spodoptera frugiperda. J Chem Ecol. 32(5):1085-1099.

Bret BL, Larson LL, Schoonover JR, Sparks TC, Thompson G.D. 1997. Biological properties of Spinosad. Down Earth. 52(1):6-13.

Busato GR, Grützmacher AD, Oliveira AC, Vieira EA, Zimmer PD, Kopp MM, Bandeira JM, Magalhães TR. 2004. Análise da estrutura e diversidade molecular de populações de Spodoptera frugiperda (J.E. Smith) (Lepidoptera: Noctuidae) associadas às culturas de milho e arroz no Rio Grande do Sul. Neotrop Entomol. 33(6):709-716.

Cisneros J, Perez JA, Penagos DI, Ruiz VJ, Goulson D, Caballero P, Cave RD, Williams T. 2002. Formulation of a nucleopolyhedro virus with boric acid for control of Spodoptera frugiperda (Lepidoptera: Noctuidae) in maize. Biol Control. 23(1):87-95.

Costa MAG, Grutzmacher AD, Martins JFS, Costa EC, Storch G, Stefanello Júnior GJ. 2005. Eficácia de diferentes inseticidas e de volumes de calda no controle de Spodoptera frugiperda nas culturas do milho e sorgo cultivados em várzea. Cienc Rur. 35(6):1234-1242.

Crouse GD, Sparks TC, Schoonover J, Gifford J, Dripps J, Bruce T, Larson LL, Garlich J, Hatton C, Hill RL, Worden TV, Martynow JG. 2001. Recent advances in the chemistry of spinosyns. Pest Manage Sci. 57(2):177-185.

Cruz I, Turpin FT. 1982. Efeito da Spodoptera frugiperda em diferentes estádios de crescimento da cultura de milho. Pesq Agropec Bras. 17(3):355-359.

Cruz I, Turpin FT. 1983. Yield impact of larval infestation of the fall armyworm Spodoptera frugiperda (J. E. Smith) to mid-whorl growth stage of corn. J Econ Entomol. 76(5):1052-1054.

Cruz I, Santos JP. 1984. Diferentes bicos do tipo leque no controle da lagarta-do-cartucho em milho. Pesq Agropec Bras. 19(1):1-7.

Cruz I. 1995. A lagarta-do-cartucho na cultura do milho (Circular Técnica, 21). Sete Lagoas: EmbrapaCNPMS, 1995. 45 p.

Cruz I, Oliveira LJ, Vasconcelos CA. 1996. Efeito do nível de saturação de alumínio em solo á cido sobre os danos de Spodoptera frugiperda (J. E. Smith) em milho. An Soc Entomol Bras. 25(2):293297.

Cruz I, Figueiredo MLC, Valicente FH, Oliveira AC. 1997. Application rate trials with a nuclear polyhedrosis virus to control Spodoptera frugiperda (Smith) on maize. An Soc Entomol Bras. 26(1):145-152.

Cruz I, Figueiredo MLC, Oliveira AC, Vasconcelos CA. 1999. Damage of Spodoptera frugiperda (Smith) in different maize genotypes cultivated in soil under three levels of aluminium saturation. Int $\mathrm{J}$ Pest Manage. 45(4):293-296. 
Cruz I, Gonçalves EP, Figueiredo MLC. 2002. Effect of a nuclear polyhedrosis virus on Spodoptera frugiperda (Smith) (Lepidoptera: Noctuidae) larvae, its damage and yield of maize crop. Rev Bras Milho e Sorgo. 1(2):20-27.

Cruz I. 2008. Manejo de pragas. In: Cruz JC, Karam D, Monteiro MA, Magalhães PC, editors. A cultura do milho. Brasília: Embrapa Informação Tecnológica. p. 303-362.

Cruz I, Figueiredo MLC, Silva RB, Foster JE. 2010a. Efficiency of chemical pesticides to control Spodoptera frugiperda and validation of pheromone trap as a pest management tool in maize crop. Rev Bras Milho e Sorgo. 9(2):20-27.

Cruz I, Figueiredo MLC, Silva RB. 2010b. Monitoramento de adultos de Spodoptera frugiperda (J. E. Smith) (Lepidoptera: Noctuidae) e Diatraea saccharalis (Fabricius) (Lepidoptera: Pyralidae) em algumas regiões produtoras de milho no Brasil. Sete Lagoas: Embrapa Milho e Sorgo, 42 p. (Embrapa Milho e Sorgo. Documentos, 93).

Farias PRS, Barbosa JC, Busoli AC. 2001. Amostragem seqüencial (presença-ausência) para Spodoptera frugiperda (J.E. Smith) (Lepidoptera: Noctuidae) na cultura do milho. Neotrop Entomol. 30(4):691-695.

Farias-Rivera LA, Hernandez-Mendoza JL, Molina-Ochoa J, Pescador-Rubio A. 2003. Effect of leaf extracts of teozinte, Zea diploperennis L., and a Mexican maize variety, criollo "Uruapeño," on the growth and survival of the fall armyworm (Lepidoptera: Noctuidae). Florida Entomol. 86(3):239-243.

Ferreira DF. 2000. Sistema SISVAR para análises estatísticas: Manual de orientação. Lavras: Universidade Federal de Lavras/Departamento de Ciências Exatas. 37 p.

Fernandes OD, Parra JRP, Neto AF, Pícoli R, Borgatto AF, Demétrio CGB. 2003. Efeito do milho geneticamente modificado MON810 sobre a lagarta-do-cartucho Spodoptera frugiperda (J. E. Smith, 1797) (Lepidoptera: Noctuidae). Rev Bras Milho e Sorgo. 2(2):25-35.

Figueiredo MLC, Cruz I, Della Lucia TMC. 1999. Controle integrado de Spodoptera frugiperda (Smith \& Abbott) utilizando-se o parasitóide Telenomus remus Nixon. Pesq Agropec Bras. 34(11):19751982.

Figueiredo MLC, Martins-Dias AMP, Cruz I. 2006. Relação entre a lagarta do cartucho e seus agentes de controle biológico natural na produção de milho. Pesq Agropec Bras. 41(12):1693-1698.

González E, Caballero N. 1990. Evaluación de trampas provistas con el atrayente (Z)-9-tetradecen-1ol acetato en relación a la captura de Spodoptera frugiperda (Smith) (Lepidoptera: Noctuidae). Bol Entomol Venez. 5(3):213-218.

Groot AT, Marr M, Schöfl, G, Lorenz S, Svatos A, Heckel DG. 2008. Host strain specific sex pheromone variation. Front Zool. 5:20.

Gross HR, Carpenter JE. 1991. Role of the fall armyworm (Lepidoptera: Noctuidae) and other factors in the capture of bumblebees (Hymenoptera: Apidae) by universal moth traps. Environ Entomol. 20(1):377-381.

Gutiérrez-Martínez A, Llanderal CL, Zarate de Lara G, Alatorre R. 1989. Fluctuación poblacional de Spodoptera frugiperda (J. E. Smith) (Lepidoptera: Noctuidae). Agrociencia. 76(2):167-174.

Hruska AJ, Gould F. 1997. Fall armyworm (Lepidoptera: Noctuidae) and Diatraea lineolata (Lepidoptera: Pyralidae): impact of larval population level and temporal occurrence on maize yield in Nicaragua. J Econ Entomol. 90(2):611-622.

Hunt LM, Ojanguren RT, Schwartz N, Halperin D. 1999. Balancing risks and resources: applying pesticides without safety equipment in southern Mexico. In: Hahn R, editor. Anthropology in public health. Oxford: Oxford University Press. p. 265-289.

Lima ER, McNeil JN. 2009. Female sex pheromones in the host races and hybrids of the fall armyworm, Spodoptera frugiperda (Lepidoptera: Noctuidae). Chemoecology. 19:29-36. 
Lopez-Edwards M, Hernández-Mendoza JL, Pescador-Rubio A, Molina-Uchoa J, Lezama-Gutiérrez R, Hamm JJ, Wiseman BR. 1999. Biological differences between five populations of fall armyworm (Lepidoptera: Noctuidae) collected from corn in Mexico. Florida Entomol. 82(2):254262.

Lopez JD, Shaver Jr. TN, Goodenough JL. 1990. Multispecies trapping of Helicoverpa (Heliothis) zea, Spodoptera frugiperda, Pseudaletia unipuncta, and Agrotis ipsilon (Lepidoptera: Noctuidae). J Chem Ecol. 16(12):3479-3491.

Malo EA, Cruz-Lopez L, Valle-Mora J, Virgen A, Sánchez JA, Rojas JC. 2001. Evaluation of commercial pheromone lures and traps for monitoring male fall armyworm (Lepidoptera: Noctuidae) in the coastal region of Chiapas, Mexico. Florida Entomol. 84(4):659-664.

Malo EA, Bahena F, Miranda MA, Valle-Mora J, 2004. Factors affecting the trapping of males of Spodoptera frugiperda (Lepidoptera: Noctuidae) with pheromones in Mexico. Florida Entomol. 87(3):288-293.

McConnell R, Hruska A. 1993. An epidemic of pesticide poisoning in Nicaragua: implications for prevention in developing countries. Am J Pub Health. 83(11):1559-1562.

Mendez WA, Valle J, Ibarra JE, Cisneros J, Penagos DI, Williams T. 2002. Spinosad and nucleopolyhedrovirus mixtures for control of Spodoptera frugiperda (Lepidoptera: Noctuidae) in maize. Biol Control. 25(2):195-206.

Mitchell ER, Tumlinson JH, McNeil JN. 1985. Field evaluation of commercial pheromone formulations and traps using a more effective sex pheromone blend for the fall armyworm (Lepidoptera: Noctuidae). J Econ Entomol. 78(6):1364-1369.

Mitchell ER, Agee HR, Heath RR. 1989. Influence of pheromone trap color and design on the capture of male velvetbean caterpillar and fall armyworm moths (Lepidoptera: Noctuidae). J Chem Ecol. 15(6):1775-1784.

Molina-Ochoa J, Lezama-Gutíerrez R, González-Ramírez M, López-Edwards M, Rodríguez-Vega MA, Arceo-Palacios F. 2003. Pathogens and parasitic nematodes associated with populations of fall armyworm (Lepidoptera: Noctuidae). Florida Entomol. 86(3):244-254.

Musser FR, Shelton AM. 2003. Bt sweet corn and selective insecticides: their impacts on sweet corn pests and predators. J Econ Entomol. 96(1):71-80.

Nagoshi RN, Meagher RL. 2004. Behavior and distribution of the two fall armyworm host strains in Florida. Florida Entomol. 87(4):454-460.

Ostle B, Mensing RW. 1975. Statistics in research. 3rd ed. Ames: Iowa State University Press.

Pacheco-Covarrubias JJ. 1993. Monitoring insecticide resistance in Spodoptera frugiperda populations from the Yaqui Valley, Son., Mexico. Resist Pest Manage News. 5(1):3-4.

Pair SD, Raulston JR, Sparks AN, Sims SR, Sprenkel RK, Douce GK, Carpenter JE. 1989. Pheromone traps for monitoring fall armyworm, Spodoptera frugiperda (Lepidoptera: Noctuidae), populations. J Entomol Sci. 24(1):34-39.

Rezende MAA, Cruz I, Della Lucia TMC. 1995. Aspectos biológicos do parasitóide Chelonus insularis (Cresson) (Hymenoptera, Braconidae) criados em ovos de Spodoptera frugiperda (Smith) (Lepidoptera, Noctuidae). Rev Bras Zool. 12(4):779-784.

Rojas JC, Virgen A, Malo EA. 2004. Seasonal and nocturnal flight activity of Spodoptera frugiperda males (Lepidoptera: Noctuidae) monitored by pheromone traps in the coast of Chiapas, Mexico. Florida Entomol. 87(4):496-503.

Scott, AJ, Knott, MA. 1974. Cluster analysis method for grouping means in the analysis of variance. Biometrics. 30(2):507-512. 
Sparks TC, Thompson GD, Kirst HA, Hertlein MB, Larson LL, Worden TV, Thibault ST. 1998. Biological activity of the spinosyns, new fermentation derived insect control agents, on tobacco budworm (Lepidoptera: Noctuidae) larvae. J Econ Entomol. 91(6):1277-1283.

Tinoco-Ojanguren R, Halperin D. 1998. Poverty, production and health: inhibition of erythrocyte cholinesterase through occupational exposure to organophosphate insecticides in Chiapas, Mexico. Arch Environ Health. 53(1):29-35.

Tomquelski GV, Martins GLM. 2007. Eficiência de inseticidas sobre Spodoptera frugiperda (J.E. Smith, 1797) (Lepidoptera: Noctuidae) em milho na região dos chapadões. Rev Bras Milho e Sorgo. 6(1):26-39.

Virla EG, Alvarez A, Loto, F, Pêra LM, Baigorí M. 2008. Fall armyworm strains (Lepidoptera: Noctuidae) in Argentina, their associate host plants and response to different mortality factors in laboratory. Florida Entomol. 91(1):63-69.

Weber DC, Ferro DN. 1991. Nontarget noctuids complicate integrated pest management monitoring of sweet corn with pheromone traps in Massachusetts. J Econ Entomol. 84(4):1364-1369.

Williams T, Valle J, Viñuela E. 2003. Is the naturally derived insecticide Spinosad compatible with insect natural enemies? Biocontrol Sci Technol. 13(5):459-475.

Wyckhuys KAG, O'Neil RJ. 2006. Populations dynamics of Spodoptera frugiperda (Smith) (Lepidoptera: Noctuidae) and associated arthropod natural enemies in Honduran subsistence maize. Crop Protect. 25(11): 1180-1190.

Yano BL, Bond DM., Novilla MN, McFadden LG, Reasor MJ. 2002. Spinosad insecticide: subchronic and chronic toxicity and lack of carcinogenicity in Fischer 344 rats. Toxicol Sci. 65(2):288-298.

Yu SJ, Nguyen SN, Abo-Elghar GE. 2003. Biochemical characteristics of insecticide resistance in the fall armyworm, Spodoptera frugiperda (J.E. Smith). Pestic Biochem Phys. 77(1):1-11. 